\title{
Measuring the relative efficiency of Canadian versus US banks
}

\author{
Mohammad Reza Ghaeli ${ }^{\text {a* }}$
}

${ }^{a}$ Faculty of Computer Studies and Information Systems, Douglas College, New Westminster, Canada

\begin{tabular}{l}
\hline C H R O N I C L E \\
\hline Article history: \\
Received June 3, 2018 \\
Received in revised format June \\
112018 \\
Accepted September 42018 \\
Available online \\
September 42018 \\
\hline Keywords: \\
Data envelopment analysis \\
DEA \\
Efficiency \\
Bank \\
Canadian banking industry \\
\hline
\end{tabular}
A B S T R A C T

\begin{abstract}
During the past three decades, data envelopment analysis (DEA) has been successfully used for measuring the relative efficiency of financial or non-financial firms. This paper presents an empirical investigation to measure the relative efficiency of five Canadian banks versus 6 US big banks using DEA method. The study considers the number of employees and total assets as input and net revenue is used as the output of the DEA model. The data are collected from the official statements of the banks for the fiscal year of 2017. The results indicate that 6 US banks maintained an average efficiency of 0.87 but the average efficiency of Canadian banks was 0.72 . While two US banks maintained an efficiency of one, the other US banks demonstrate relatively well in terms of the performance. In Canada, while one bank performed relatively well, the performance of the other Canadian banks were not as good as the US banks.
\end{abstract}

(C) 2019 by the authors; licensee Growing Science, Canada

\section{Introduction}

Efficiency plays an important role for the success of the most financial institutions such as insurance companies, banks, etc. (Holod \& Lewis, 2011). Data envelopment analysis (DEA) is one of the tools for measuring the relative efficiency of different financial or non-financial firms. The benefit of applying DEA is that it makes it possible to use the non-financial factors along with the financial data to reach a better comparison of various units. DEA has become a popular technique among scholars because of the simplicity of the implementation and interpretation. During the past three decades, there have been substantial works on applying DEA models for estimating the relative efficiency of banks in the world (Haslem et al., 1999; Mercan et al., 2003). Yang et al. (2010), for instance provided an integrated bank performance evaluation and management planning based on a hybrid minimax reference point - DEA approach.

Staub et al. (2010) performed an investigation on various factors influencing on the relative efficiency of Brazilian banks such as cost and technical efficiencies over the period 2000-2007. They stated that Brazilian banks were blamed for low levels of efficiency compared with European or US banks. They also stated that state-owned banks were substantially more cost efficient than other foreign banks. Nevertheless, they could not detect any evidence to learn that the differences in economic efficiency

* Corresponding author.

E-mail address: rghaeli@nyit.edu (M. Reza Ghaeli) 
were because of the type of activity and bank size. Avkiran (2010) looked for the association between the supper-efficiency estimations and some financial factors of Chinese banks. They detected the inefficient units where there was a low correlation between the supper-efficiency and good financial ratios. Lin et al. (2009) applied various DEA techniques for 117 branches of a certain bank in Taiwan and found an overall technical efficiency of 54.8 percent for all banks. The results of their study also indicated that most branches were relatively inefficient.

Thoraneenitiyan and Avkiran (2009) performed an investigation by using a hybrid of DEA and SFA to measure the effect of restructuring and country-specific factors on the efficiency of post-crisis East Asian banking systems over the period 1997-2001. They stated that banking system inefficiencies were primarily contributed to country-specific conditions, such as high interest rates, markets mixture, etc. DEA was also implemented for banking decisions. For example, Che et al. (2010) applied a hybrid of Fuzzy analytical hierarchy procedure (AHP) (Saaty, 1985, 1990, 2003; Chang, 1996) and DEA as a decision making facility for making decisions on bank loan. Chen et al. (2018) investigated the efficiency of Chinese banks during the peak period of the global financial crisis. They implemented an innovative DEA technique under a stochastic environment. The results disclosed that the overall efficiency level of the Chinese banks were low.

Fujii et al. (2018) estimated bank efficiency and productivity changes in the EU28 countries and reported that bank efficiency was undermined by the financial crisis in banks notably from the EU15 countries. Wanke et al. (2018) compared different DEA techniques for measuring the relative efficiency of banks and reported that we may reach different results depending on the type of model, inputs and outputs. Fernandes et al. (2018) measured the relative efficiency of peripheral European banks and computed the effects of bank-risk determinants on their performance over the period 2007-2014. DEA was implemented based on a Malmquist Productivity Index in order to calculate the bank efficiency scores. The results maintained important policy implications for the Euro area, as they indicated the existence of a periphery efficiency meta-frontier. Liquidity and credit risk were detected to negatively influence on banks productivity, whereas capital and profit risk maintained a positive effect on their performance.

\section{Data Envelopment Analysis}

In constant return to scale DEA (CCR) introduced by Charnes, et al. $(1978,1994)$, one measures the relative efficiency of a given decision making unit (DMU). In many cases, reaching an analytical form for the performance function is impossible. Thus, it is possible to form a set of production feasibility, which constitutes of some principles such as fixed-scale efficiency, convexity and feasibility as follows,

$$
T_{C}=\left\{(X, Y) \mid X \geq \sum_{j=1}^{n} \lambda_{j} X_{j}, Y \leq \sum_{j=1}^{n} \lambda_{j} Y_{j}, \lambda_{j} \geq 0, j=1, \cdots n\right\},
$$

where $X$ and $Y$ state the input and the output vectors, respectively. The CCR production feasibility set border describes the relative efficiency in which any off-border DMU is considered as inefficient. The CCR model is presented in two forms of either input or output oriented. The input CCR tries to decrease the maximum input level with a ratio of $\theta$ such that, at least, the same output is produced, i.e.:

$$
\begin{aligned}
& \min \quad \theta \\
& \text { subject to } \\
& \theta X_{p}-\sum_{j=1}^{n} \lambda_{j} X_{i j} \geq 0, \\
& \sum_{j=1}^{n} \lambda_{j} Y_{r j} \geq Y_{r p}, \\
& \lambda_{j} \geq 0, \quad j=1, \cdots, n .
\end{aligned}
$$


Model (2) is the envelopment form of input CCR where $\theta$ is the relative efficiency of the DMU and we can show that the optimal value of $\theta, \theta^{*}$, is always between zero and one. In an input oriented DEA model, once the efficiency of a DMU unit, $D M U_{p}$, drops, one may use the border to make it efficient.

For the case of the output oriented DEA model, the primary objective is to maximize the output level, $\varphi$, by applying the same amount of input. The model can be formulated as follows,

$$
\begin{aligned}
& \min \varphi \\
& \text { subject to } \\
& \sum_{j=1}^{n} \lambda_{j} X_{i j} \leq X_{i p}, \\
& \sum_{j=1}^{n} \lambda_{j} Y_{j} \geq \varphi Y_{i p}, \\
& \lambda_{j} \geq 0, \quad j=1, \cdots, n .
\end{aligned}
$$

\section{The proposed method}

This paper presents an empirical investigation to measure the relative efficiency of five Canadian banks versus 6 US big banks using DEA method. The study considers the number of employees and total assets as input and net revenue is used as the output of the DEA model. The data are collected from the official statements of the banks for the fiscal year of 2017. Table 1 demonstrates some basic information about the banks. In Canade, five banks; namely TD Bank, Nova Scotia, Royal Bank, Canadian imperial bank of commerce (CIBC) and Bank of Montreal represent the biggest financial institutions for serving Canadians. Note that since DEA implementation requires positive numbers for the input and output, we have not considered the information of CITI Group because this firm reported a negative loss of 6.798 billion dollar during the fiscal year of 2017. In our survey, total assets and net incomes are in billion dollars. Fig. 1 shows the inputs and the output of the DEA model.

\section{Table 1}

Basic statistics of some big Canaidan and US banks

\begin{tabular}{lccc}
\hline Bank name & Number of Employee & Total Assets & Net Income \\
\hline Canadian imperial bank of commerce (CIBC) & 44928 & 435.2502 & 3.6344 \\
Royal Bank & 79308 & 977.9 & 6.4295 \\
TD Bank & 85000 & 924 & 8.085 \\
Nova Scotia & 88645 & 704.781 & 6.314 \\
Bank of Montreal & 45200 & 423.84342 & 3.1955 \\
JPMorgan Case & 166937 & 2534 & 24.441 \\
Bank of America & 209000 & 2281 & 18.232 \\
Wells Fargo & 262700 & 1952 & 22.183 \\
Goldman Sachs & 37300 & 916.776 & 4.286 \\
Morgan Stanley & 55311 & 814.95 & 5.98 \\
U.S. Bancorp & 72402 & 462.04 & 6.218 \\
\hline
\end{tabular}

Source: Official financial statements of the firms

As we can observe from the Fig. 1, the DEA model consists of two inputs and one output. Fig. 2 shows the results of the implementation of the proposed model. The results indicate that six US banks maintained an average efficiency of 0.87 while the average efficiency of Canadian banks was 0.72 . While two US banks maintained an efficiency of one, the other US banks demonstrate relatively well in terms of the performance. 


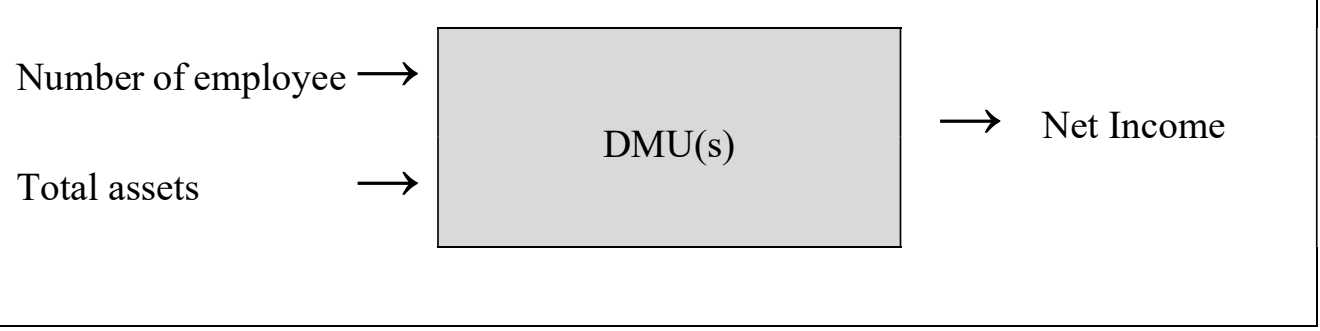

Fig. 1. The propsoed DEA model

In Canada, while one bank performed relatively well, the performance of the other Canadian banks were not as good as the US banks. It appears that US banks used to perform better than some South American banks. As stated earlier, Staub et al. (2010) performed a study on various factors influencing on the relative efficiency of Brazilian banks such as cost and technical efficiencies over the period 2000-2007 and in this work Brazilian banks were blamed for low levels of efficiency compared with European or US banks. However, as Staub et al. (2010) reported, the average efficiency was reported to be about 57\% for Brazilian banks while Canadian banks performed better in our report.

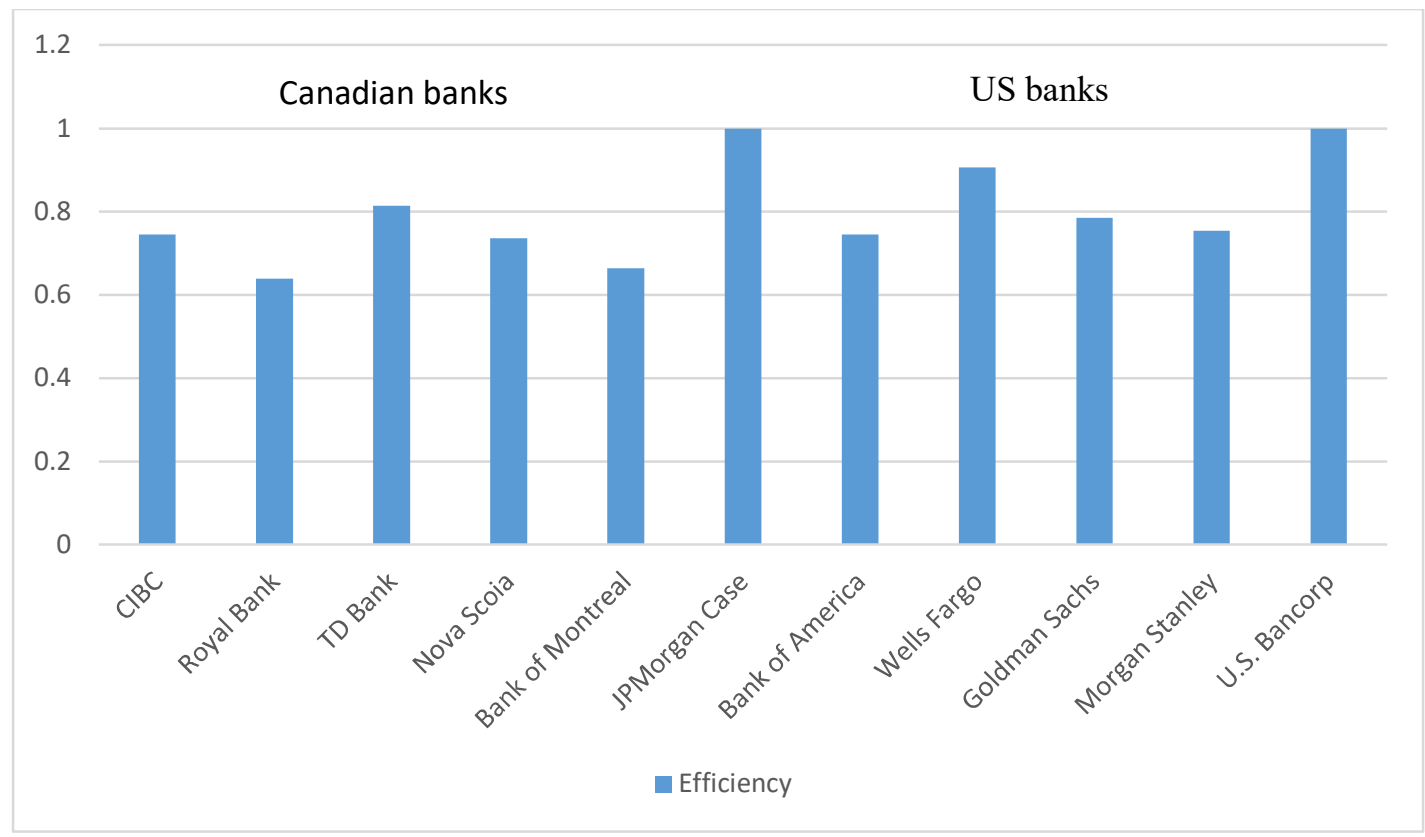

Fig. 2. The results of measuring the relative efficiency of US versus Canadian banks

\section{Conclusion}

Measuring the relative performance of banks, insurances and other financial institutions have been a concern among banks' customers, investors, government agencies, etc. It helps customers keep their accounts with banks with better performance while investors may find some bargin for investment planning. In this paper, we have performed an empricial investigation to measure the relative efficiency of 11 North American banks. The study has chosen 5 big Canadian versus 6 giant US banks and using DEA technique the relative efficiency of these banks have been measured. Our survey has shown that 
US firms are in better position in terms of efficiency compared with Canadian banks. Other studies have also confirmed that US banks performed better than some South American banks (Staub et al. 2010; Che et al., 2010).

\section{Acknowledgment}

The authors would like to thank the anonymous referees for their comments on the earlier version of this work.

\section{References}

Avkiran, N. K. (2010). Association of DEA super-efficiency estimates with financial ratios: Investingating the case for Chinese banks. Omega, doi:10.1016/j.omega.2010.08.001.

Chang, D. Y. (1996). Applications of the extent analysis method on fuzzy AHP. European Journal of Operational Research, 95(3), 649-655.

Charnes A, Cooper, W. W., Rhodes, E. (1978). Measuring the efficiency of decision making units. European Journal of the Operational Research, 2, 429-44.

Charnes A, Cooper W. W., Lewin, A., Seiford, L. M. (1994). Data envelopment analysis: theory, methodology and applications. Massachusetts: Kluwer Academic Publishers.

Che, Z. H., Wang, H. S., \& Chuang, Ch-L. (2010). A fuzzy AHP and DEA approach for making bank loan decisions for small and medium enterprises in Taiwan, Expert Systems with Applications, 37(10), 7189-7199.

Chen, Z., Matousek, R., \& Wanke, P. (2018). Chinese bank efficiency during the global financial crisis: A combined approach using satisficing DEA and Support Vector Machines it. The North American Journal of Economics and Finance, 43, 71-86.

Fernandes, F. D. S., Stasinakis, C., \& Bardarova, V. (2018). Two-stage DEA-Truncated Regression: Application in banking efficiency and financial development. Expert Systems with Applications, 96, 284-301.

Fujii, H., Managi, S., Matousek, R., \& Rughoo, A. (2018). Bank efficiency, productivity, and convergence in EU countries: a weighted Russell directional distance model. The European Journal of Finance, 24(2), 135-156.

Haslem, J. A., Scheraga, C. A., \& Bedingfield, J. P. (1999). DEA efficiency profiles of U.S. banks operating internationally. International Review of Economics \& Finance, 8(2), 165-182.

Holod, D., \& Lewis, H. F. (2011). Resolving the deposit dilemma: A new DEA bank efficiency model. Journal of Banking \& Finance, 35(11), 2801-2810.

Lin, T. T., Lee, Ch-Ch., \& Chiu, T-F. (2009). Application of DEA in analyzing a bank's operating performance. Expert Systems with Applications, 36(5), 8883-8891.

Mercan, M., Reisman, A., Yolalan, R., \& Burak Emel, A. (2003). The effect of scale and mode of ownership on the financial performance of the Turkish banking sector: results of a DEA-based analysis, Socio-Economic Planning Sciences, 37(3), 185-202.

Saaty, T. L. (1985). Decision making for leaders. IEEE Transactions on Systems, Man, and Cybernetics, (3), 450-452.

Saaty, T. L. (1990). An exposition of the AHP in reply to the paper "remarks on the analytic hierarchy process". Management science, 36(3), 259-268.

Saaty, T. L. (2003). Decision-making with the AHP: Why is the principal eigenvector necessary. European journal of operational research, 145(1), 85-91.

Staub, R. B., Da Silva e Souza, G. \& Tabak, B. M. (2010). Evolution of bank efficiency in Brazil: A DEA approach. European Journal of Operational Research, 202(1), 204-213.

Thoraneenitiyan, N., \& Avkiran, N. K. (2009). Measuring the impact of restructuring and countryspecific factors on the efficiency of post-crisis East Asian banking systems: Integrating DEA with SFA. Socio-Economic Planning Sciences, 43(4), 240-252. 
Yang, J.B., Wong, B.Y.H., Xu, D.L., Liu, X.B. \& Steuer, R.E. (2010). Integrated bank performance assessment and management planning using hybrid minimax reference point - DEA approach. European Journal of Operational Research, doi:10.1016/j.ejor.2010.07.001.

Wanke, P., Barros, C. P., \& Emrouznejad, A. (2018). A comparison between stochastic DEA and fuzzy DEA approaches: revisiting efficiency in Angolan banks. RAIRO-Operations Research, 52(1), $285-$ 303.

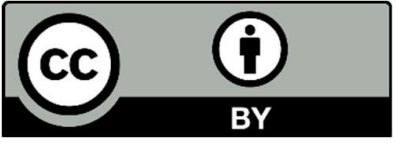

(C) 2019 by the authors; licensee Growing Science, Canada. This is an open access article distributed under the terms and conditions of the Creative Commons Attribution (CC-BY) license (http://creativecommons.org/licenses/by/4.0/). 